\title{
Expanding Vistas of Mongolia-Russia Strategic Partnership since 2000 Ulaanbaatar Declaration
}

\author{
Vaishali Krishna \\ Currently ICSSR Post-Doctoral Fellow at the Centre for Inner Asian Studies, \\ School of International Studies, Jawaharlal Nehru University, New Delhi.
}

\section{Introduction}

$\mathrm{O}$ n September 7, 2017, while meeting with the Russian President Vladimir Putin on the sidelines of the Eastern Economic Forum held in Vladivostok, the Mongolian President Khaltmagiin Battulga made it amply clear that his priority now is "to promote the advancement of Mongolia-Russia relations, including economic cooperation, to a new level." This is no surprise given that Battulga matched his July 2017 presidential election campaign hostility toward China with a pro-Russia platform. ${ }^{2}$ On further contemplation, however, one can identify three main driving forces behind Mongolia-Russia expanding partnership: "First, in contrast to former Soviet Bloc states in Europe that have been moving closer to the EU in recent years, Mongolia has spent the last decade actively strengthening its ties with Russia across a range of sectors. Second, cooperation between the two states is developing for Mongolia in ways that allow it more room for manoeuvre within its largely confining regional geographic position.

1 President of Russia, "Meeting with President of Mongolia Khaltmaagiin Battulga", 7 September 2017, http://en.kremlin.ru/events/president/news/55551(accessed 28 October 2017).

2 Sharad K Soni (2017), "Mongolia's new president is Mongolia first and China last", East Asia Forum, 11 August, http://www.eastasiaforum.org/2017/08/11/mongolias-new-president-ismongolia-first-and-china-last/\#more-81340 (accessed 28 October 2017).

This article is published under the Creative Commons CC-BY-ND License

(http://creativecommons.org/licenses/by-nd/4.0/). This license permits use, distribution and reproduction, commercial and non-commercial, provided that the original work is properly cited and is not changed anyway. 
Third, Russia has re-emerged as an important partner to balance China; a state on which Mongolia is increasingly, and uncomfortably, dependent." 3 In recent years, the focus of Mongolia-Russia relationship has essentially been on strengthening and expanding their strategic partnership. Evidently, last year in April 2016, an important event took place when Russian Foreign Minister Sergey Viktorovich Lavrov signed a mid-term programme agreement with his Mongolian counterpart for the development of a strategic partnership between the two countries. ${ }^{4}$ This points to the fact that ever since Mongolia-Russia Ulaanbaatar Declaration was signed in 2000 there have been positive developments in the bilateral relationship which needs to be examined in the backdrop of the evolution of strategic partnership between the two sides.

\section{Evolution of Strategic Partnership}

The geo-strategic importance of Mongolia due to its landlocked geographical location between Russia and China is the primary reason for both Russia and Mongolia to have cordial relations with each other. ${ }^{5}$ By pursuing its third neighbour foreign policy with a balancing approach towards its two geographic neighbours- Russia and China, Mongolia has looked for a place in the post-cold war world and has overcome isolation to create a stable and favourable external environment. As a result, Mongolia's foreign relations posture shed its deep-seated dependence on the former Soviet Union and shifted towards a policy of nonalignment shaped by balanced relations with Russia and China as well as with the US and other Western powers. ${ }^{6}$ The entire policy on foreign relations was shifted alongside the structural transition. Not only did Japan and the US welcome this shift in foreign policy but also other powers in the Asia-Pacific, especially in view of Mongolia's geopolitical constraints of being a vast territorial buffer between Russia and China. Yet, the post-Soviet shift in Mongolia's foreign policy also witnessed the beginning of a new era in

Jeff Reeves (2015), "Russo-Mongolian Relations: Closer than Ever", Russian Analytical Digest, No. 161, 30 January 2015, p.2.

4 Oyundari Erdenebat (2016), "Mongolia and Russia sign mid-term program agreement to develop strategic partnership", UB Post, 15 April, http://theubpost.mn/2016/04/15/mongoliaand-russia-sign-mid-term-program-agreement-to-develop-strategic-partnership/(accessed 29 October 2017).

5 Sharad K Soni (2002), Mongolia-Russia Relations: Kiakhta to Vladivostok, Delhi: Shipra Publications, p.8.

6 D. Bayarkuu (2001), "Mongolia and its Third Neighbours", Himalayan and Central Asian Studies, 5(1): 84. 
Mongolia-Russia bilateral relations.

Quite different from the Soviet period when dependence and domination were the two fundamental features characterizing bilateral ties between Russia and Mongolia, the post-Soviet period has seen a diverse pattern that is based on "equality" in the relationship on the whole. In the beginning, the political relations began to take shape primarily through exchange of high level visits between the two sides. But these visits did not pay much dividend as there had been a clear state of stagnation in their relations until the year 2000 when the Russian President Vladimir Putin paid a visit to Mongolia. Putin's visit followed an improvement in bilateral relations in 1999 mainly due to the China factor as Chinese domination in Mongolian economy was clearly visible. Russia then realized the geostrategic importance of Mongolia in the light of Chinese presence which also raised Russian concerns for the security of its eastern borders. On its part, Mongolia too became eager to strengthen its ties with Russia.

Startlingly, in December 1999 a long-awaited meeting between Russian President Boris Yeltsin and Mongolian President N. Bagabandi took place in Kremlin to discuss several important issues of mutual concerns in almost all areas- political, economic, cultural and military. In 2000, Putin's visit to Ulaanbaatar was aimed at improving the bilateral relations which had been facing stagnation for almost a decade. The credit for improvement in relations was also given to the overwhelming victory of the Mongolian People's Republican Party (MPRP) by defeating the Democrats in the June 2000 parliamentary elections. As such Putin's visit, combined with the MPRP victory, regenerated the hope for Russia and Mongolia to resume and promote their traditional ties. This, in the following years, eventually gave a strong push to their so called "halted" relations and marked the return of Russia's comprehensive cooperation with Mongolia. Since Mongolia's greatest importance to Russia lies in its geopolitical location, ${ }^{7}$ it was considered to be in the interest of Moscow to renew its relations with Ulaanbaatar.

Russian leaders were hopeful that President Putin's Ulaanbaatar visit in 2000 would help re-establish Moscow's preeminent position as a most favoured neighbour. ${ }^{8}$ The leaders of the two States held a thorough exchange of views on a broad range of issues relating to their bilateral relations and on international issues of mutual concerns, which culminated in the signing of the Ulaanbaatar Declaration that was christened as "a legal groundwork for the restoration of

R. Bold (1994), "The Changing International Order and Mongolia's Security," The Mongolian Journal of International Affairs (Ulaanbaatar), (1):10.

8 Nomin Lhagvasuren (2000), "Russia Seeks to Restore Position in Mongolia as Most Favoured Neighbour”, Eurasia Insight, 17 November, http://www.eurasianet.org/departments/insight/ articles/eav111700.shtml (accessed 29 October 2017). 
bilateral ties between the two countries". ${ }^{9}$ Since the signing of the Ulaanbaatar Declaration the two sides have seen several high level exchanges of visits including the 2002 visit of Russian Prime Minister Mikhail Kasyanov who became the first head of cabinet to come to Mongolia since 1971. However, the significance of Ulaanbaatar Declaration lies into the fact that it was a document, which determined the principles of directions for extending and developing Mongolia-Russia relations in the 21 st century. ${ }^{10}$

Further in 2003, the two countries established their good neighbourly and traditional partnership during the visit of the then Mongolian Prime Minister Nambaryn Enkhbayar to Russia. The result was that in December 2003, the Russian government decided to write off almost the entire Soviet-era Mongolia's debt to Russia, once valued at US \$ 11 billion. ${ }^{11}$ This gave a boost to bilateral economic relations which were overshadowed since the Soviet collapse in 1991. Such a boost, however, did not encourage Russian investment until political relations set a new landmark in 2006. In that year, Mongolia-Russia political relations entered in to a resumption phase when "Moscow Declaration" was signed during a second visit to Russia by Nambaryn Enkhbayar after he took over Mongolia's command as the new President. Moscow Declaration was a document in which both sides set in place their mutual aspiration to increase the efficiency of bilateral interaction in the spirit of strategic partnership. ${ }^{12}$

One may discover that in the post-2000 period, the treaties and agreements signed in various areas of cooperation on interstate and intergovernmental levels have become the basis for the expansion of Mongolia-Russia bilateral relations. Initially, the relationship between the two sides was guided by the Treaty on Friendly Relations and Cooperation between Russia and Mongolia of January 20, 1993 and the Ulaanbaatar Declaration of November 14, 2000. Indeed it was Putin's Mongolia visit in 2000 that proved to be meaningful for peaceful relations and constructive cooperation between the two sides in the succeeding years. Both sides recognised the importance of signing bilateral agreements in a Joint Russian-Mongolian Statement issued on January 14, 2004, when the Minister of Foreign Affairs of the Russian Federation Igor Ivanov paid an

9 Sharad K Soni (2011), "Russia and Mongolia: Recent Upsurge in Ties", Defence \& Security Alert, p. 48.

10 Sharad K Soni (2006), "Mongolia's Security Thinking and Outside World: A Reappraisal", Bimonthly Journal of Mongolian and Tibetan Current Situation (Taipei), 15 (6):33.

11 Sergei Blagov (2009), "Russia boosts Mongolia ties", Asia Times, 5 June, http://www.atimes. com/atimes/Central_Asia/KF05Ag01.html (accessed 29 October 2017).

12 Elena Boykova (2010), "Russia and Mongolia: Prospects of Relations in the 21st century", in K. Warikoo and Sharad K. Soni, eds., Mongolia in the 21st Century: Society, Culture and International Relations, New Delhi and London: Pentagon, pp.234-5. 
official visit to Mongolia at the invitation of the Minister of Foreign Affairs of Mongolia Luvsangiin Erdenechuluun. ${ }^{13}$ The joint statement reflected the historically established deep mutual trust, good-neighbourliness and friendship between the peoples of Russia and Mongolia. Bilateral trade and economic cooperation revived gradually following a period of decline since1990s but it was only in 2006 that the two countries agreed to move from "traditionally good-neighbourly partnership" to "strategic partnership". ${ }^{14}$

\section{Expansion of Strategic Partnership}

The expansion of Strategic Partnership began to be felt since April 2008 when Mongolian Prime Minister Sanjaagiin Bayar paid an official visit to Moscow, which opened up what has been described as "a new era for comprehensive cooperation between the two nations." By then Moscow had already considered Mongolia as a special subject in its foreign affairs development. Politically, the frequent exchange of high-level visits between the two countries deepened their mutual trust and reliance, and hence MongoliaRussia bilateral ties entered into a new period of growth. ${ }^{15}$ The year 2009 was full of remarkable events for both Mongolia and Russia as they celebrated the $70^{\text {th }}$ anniversary of the Victory at the Battle of Khalkhyn Gol, ${ }^{16}$ and the $60^{\text {th }}$ anniversary of the Ulaanbaatar Railway that had a great significance in recalling the tradition and historical features of the relations between the two countries.

But it was on August 25, 2009 that the visit of Russian President Dmitry Medvedev to Mongolia marked the signing of a Declaration on the Development of Strategic Partnership between the two sides, thus raising the status of their relationship from being good neighbours to strategic partners. ${ }^{17}$ Not only did they sign what is known as the "manifesto to boost the strategic partnership" but also a series of

13 "Joint Russian-Mongolian Statement", 14 January 2014, Mongolian Journal of International Affairs, no.13, 2005, pp.107-11.

14 Hudson Institute (2009), Remarks by Batbold Sukhbaatar, Minister of Foreign Affairs and Trade of Mongolia on "Mongolia's Relations with Russia and China and Its third neighbor policy: Relations with U.S, Japan", Washington DC, 8 June, p.3.

15 Huo Wen and Zhang Guangzheng (2009), "Mongolia, Russia to bolster bilateral ties", People's Daily Online, 27 August, http://english.people.com.cn/90001/90780/91343/6741484 txt.html (accessed 1 November 2017).

16 Uradyn E. Bulag (2009), "The Nomonhan Incident and the Politics of Friendship on the Russia-Mongolia-China Border", The Asia-Pacific Journal, no. 48, 30 November, http:// archive.constantcontact.com/fs053/1011273691009/archive/1102854389249.html (accessed 1 November 2017).

17 Wen and Guangzheng, "Mongolia, Russia to bolster bilateral ties". 
other agreements by which the two countries pledged to consolidate cooperation in railway system updating, uranium exploitation, and a huge investment in the coal mining. Political analysts noted that "the signing of the declaration on strategic partnership development signifies the progress of vital importance scored by Russia's diplomacy towards Mongolia." 18 This was, in fact, an extension of the existing level of Russia-Mongolia relations which had been successfully developing on the basis of the 1993 Treaty on friendly relations and cooperation, Ulaanbaatar Declaration of 2000 and Moscow Declaration of 2006. All such agreements are the evidence that Russia and Mongolia are committed to strengthen their political and diplomatic relations by pursuing their strategic partnership.

Within three years the two sides proceeded further to reinforce their political and economic ties. On October 19, 2012, Sergei M. Mironov, Chairman of the Council of Inter-Parliamentary Assembly of States in the upper house (Federation Council of Russia) and Head of the Russia-Mongolia interparliamentary group, held a meeting with Mongolian Ambassador to Russia Doloonjin Idevkhten to review efforts for expanding relations between the State Duma and Mongolia's parliament. ${ }^{19}$ Mongolia thus figured prominently in the general thrust of Russia's Asian policy which called for further expansion of strategic partnership between the two sides. The fact that the Russian and Mongolian views converge on regional and global issues in the spirit of their strategic partnership can be seen through agreements incorporated into the Declaration on the development of their strategic partnership. The Declaration, in part, includes the following: ${ }^{20}$

1. Both Mongolia and Russia stressed on the desire to work together in the interests of all members of the international community to equal opportunities for development, including through the establishment of a new global financial architecture and adapt existing financial system to the current realities.

2. They made commitments to lend their support for comprehensive reform of the United Nations, including the expansion of the Security

\footnotetext{
18 Vaishali Krishna (2017), “Advancing Strategic Partnership Key to Russia-Mongolia Existing Relationship", The Dialogue, 20 January, http:/www.thedialogue.co/advancing-strategicpartnership-is-the-key-to-russia-mongolia-existing-relationship/(accessed 1 November 2017).

19 Alicia J. Campi (2012), "Mongolia and Russia Re-Invigorate Mutual Ties”, 12 November, Eurasia Daily Monitor, Jamestown Foundation, 9 (207), http://www.refworld.org/ docid/50a4d3fa2.html (accessed 1 November 2017).

20 Vaishali Krishna (2017), "Russia and Mongolia: Strengthening Strategic Partnership", World Focus (New Delhi), no.445, pp.102-103.
} 
Council, with a view to make it more representative and effective through a broad consensus of UN member states.

3. Since the spread of nuclear weapons remained a threat to international peace and security, Russia and Mongolia reaffirmed their support for the Treaty on the Non-Proliferation of Nuclear Weapons (NPT). Both sides hailed the multilateral efforts ...to move towards improving the efficiency of this treaty based on the unity of its three key components: non-proliferation, disarmament and peaceful uses of nuclear energy....

4. The two sides stressed that one of the important tools to strengthen the non-proliferation regime is to create zones in the world free of nuclear weapons. Russia pointed out that an internationally recognized nuclearfree status of Mongolia is a significant contribution to this process, and hence the entry into force on March 21, 2009 of the Treaty on a Nuclear Weapons Free in Central Asia was considered as a significant factor in ensuring security in the region.

5. They expressed their concerns over DPRK's May 25, 2009 nuclear test and urged Pyongyang to comply strictly with UN Security Council Resolution No. 1695, 1718 and 1874 to abandon nuclear weapons programmes. They also stressed on the need to work towards the resumption of negotiations in order to resolve the nuclear issue on the Korean Peninsula besides maintaining peace and stability in Northeast Asia.

6. The two countries expressed their commitment to work together to combat terrorism and other new threats and challenges. They called for the consistent implementation of the UN Global CounterTerrorism Strategy, implementation of norms of universal anti-terrorism conventions and speedy finalization of a Comprehensive Convention on International Terrorism.

7. Expressing their concerns over ongoing ideological expansion of terrorism, Russia and Mongolia confirmed the need for strict compliance with Resolution 1624 of the UN Security Council calling for a criminal offense of inciting terrorism, among civilizations, intercultural and interfaith dialogue as an effective tool to suppress terrorist ideology, bringing to this task the capacity of civil society, including business and media.

8. They also expressed their strong intention to continue close cooperation in curbing the new challenges and threats to regional sites. Mongolia in this regard expressed support for the efforts of the Regional AntiTerrorist Structure of the Shanghai Cooperation Organization (SCO) according to ... the atmosphere of peace, security and cooperation. 
9. Both sides called for the formation of a transparent and equal security system in the Asia-Pacific Region (APR) that would be based on a collective basis, international law and the interests of all countries in the region. They noted the need for an ATP partner network of multilateral organizations, close cooperation within the existing integration forums, especially the SCO and ASEAN Regional Forum (ARF) on security.

10. Russia welcomed Mongolia's desire to become a member of AsiaPacific Economic Cooperation (APEC), and stated that it will support an application to the case of the adoption of APEC consensus decision on enlargement of the forum.

11. Keeping in mind the importance of cooperation in the SCO framework, the two countries agreed to continue exchanging information and conducting bilateral and multilateral consultations on strengthening mechanisms for collaboration of member countries and observer states to implement a number of programmes within the organization in priority areas such as energy and transportation.

Subsequent to the 2009 Declaration on the development of their Strategic Partnership the two sides had long been planning to establish a full-fledged strategic partnership since September 2014, when the Russian and Mongolian Presidents met in Ulaanbaatar. At that time, among prominent economic deals Russian President Putin and Mongolian President Elbegdorj agreed to include a protocol that provided for visa-free travel of both Russian and Mongolian passport holders between the two countries for up to 30 days. This agreement, which came into effect on December 14, 2014, marked the return of diplomatic relations to the level the two sides enjoyed during the Cold War years and is, as such, a remarkable and symbolic development so far as the expansion of strategic partnership is concerned. ${ }^{21}$

However, in order to give a boost to the plan of establishing a strategic partnership Russia and Mongolia signed a medium-term program for the development of strategic partnership during Russian Foreign Minister Sergey Lavrov's official visit to Ulaanbaatar on April 14, 2016. According to the Mongolian Foreign Minister Lundeg Purevsuren, "this is not only a mediumterm plan for the development of bilateral relations, but also a kind of a compass, a benchmark for the two countries' future actions over the next five

\footnotetext{
${ }^{21}$ Jeff Reeves (2015), "Russo-Mongolian Relations: Closer than Ever", Russian Analytical Digest No. 161, 30 January,

http://www.css.ethz.ch/content/dam/ethz/special-interest/gess/cis/center-for-securities-studies/ pdfs/RAD-161-2-5.pdf (accessed 3 November 2017).
} 
years." ${ }^{22}$ This document was most desired in the ongoing circumstances because under the existing regulations, the planning of bilateral relations was being carried out only on a yearly basis based on the protocol of the RussianMongolian Intergovernmental Commission, which was not enough to realize the full potential of the strategic partnership. Both sides also held talks on strengthening economic and political cooperation at the bilateral level, joint projects with the participation of China, and further intensification of RussianMongolian interaction. They renewed the existing intergovernmental agreement on the promotion of regional and cross-border cooperation as well.

Recently, on October 2, 2017, the second Mongolia-Russia Cooperation Business Forum has once again reinforced the importance of broadening Mongolia-Russia relations and cooperation to enrich the strategic partnership. The two countries are already negotiating to create a permanent council, which would focus on upgrading the legal landscape for the commercial ties. Russian Ambassador I. K. Azizov said at the Forum that the two countries have to focus attention to forwarding their partnership without limiting it to the economic and trade sectors. ${ }^{23}$ According to him, it is vital for Russia to widen the cooperation with Mongolia in five certain directions, i.e., enhancing cooperation in the energy sector, advancing construction works of railways, promoting cooperation in new fields such as air transportation and processing industries, supplying agricultural equipment and broadening collaboration in livestock breeding.

Another noteworthy component of Russia-Mongolia strategic partnership framework has been Russia's positive posture for Mongolia's efforts of making its presence felt in the world, particularly in the Community of Democracies. During 2011-2013 Mongolia chaired the Community of Democracies, which has been both an honor and a heavy responsibility for Mongolia as its goal was to focus on promotion of democracy education, strengthening regional cooperation, providing greater support to civil society and promoting sharing of experience. ${ }^{24}$ Russia essentially is not opposed to such activities of Mongolia for the simple reason of developing democratic culture in the Asia-Pacific region. The success of democratic transition has indeed taken Mongolia to the new stage of development not only at home but also at foreign front in strengthening its bilateral and multilateral relations. ${ }^{25}$

22 "Russia and Mongolia to sign medium-term strategic partnership program", 13 April 2016, http://tass.com/politics/869238 (accessed 3 November 2017).

23 B. Batchimeg (2017), "Mongolia-Russia Business Forum Commences", Montsame, 3 October, http://montsame.mn/en/read/11728

24 Sharad K Soni (2013), "Evaluating Mongolia's Experience of Democratization: The PostSoviet Scenario", The Mongolian Journal of International Affairs, (18):30.

25 Sharad K Soni (2012), "Post-Soviet Transition in Mongolia: Gauging the Success of Democratization”, Mongolica, vol. I (45):156. 


\section{Russia-Mongolia Partnership on Regional Issues}

In line with the Declaration on the development of Strategic Partnership Russia has also been extending its support towards Mongolia's efforts of going with the regional integration and joining different groupings. Mongolia, in fact, is back on the international scene after centuries of relative isolation in the post-2000 period as it engages itself actively in international fora as well as reinforcing its integration into regional and global structures. Since RussiaMongolia relations have been developing in a spirit of strategic partnership and on the basis of mutual benefit and mutual trust, it has been observed that Russia has been committed to be supportive in Mongolia's engagement with regional organisations. Although a member of the United Nations, Mongolia has had trouble gaining full participation in broader international security dialogues. It attended the ASEAN-centered "ASEAN Regional Forum" (ARF) in Singapore and remained an OSCE Partner member since 2004 until becoming a full member in 2012. ${ }^{26}$

In the 21st century, Mongolia has become a geographic and political locus of surpassing strategic importance to the United States, Russia and China. By reviewing the dynamic of interests these three nations have in Mongolia, one can understand its importance to the broader global community of democracies i.e., OSCE and also to NATO. ${ }^{27}$ The North Atlantic Council formally approved an Individual Partnership and Cooperation Programme with Mongolia on 19 March 2012. This has not only formalized but also developed relations between NATO and Mongolia. ${ }^{28}$ Earlier, July 2005 conference of the ASEAN Regional Forum (ARF) welcomed Mongolia's accession to the Treaty of Amity and Cooperation (TAC) and then in the following year the 2006 ASEM 6 Summit invited Mongolia to become a member. The result was that Mongolia officially joined ASEM at the 2008 ASEM 7 Summit. Mongolia has also joined the Conference on Interaction and Confidence Building Measures in Asia (CICA), while at the same time seeking membership of APEC. These are all clear signs that Mongolia has been actively participating in regional groupings to make its worthy contribution internationally.

However, Russian support to Mongolia's engagement with regional organisations is more visible in the Shanghai Cooperation Organization (SCO) where it has an observer status since 2004. Recently, there have been indications

26 OSCE (2012), “A look at the OSCE's newest member, Mongolia”, 21 November, http://www. osce.org/cio/97404 (accessed 7 November 2017).

27 John J. Jr. Tkacik (2008), "Mongolia's Current Political Situation: Implications for the OSCE," no. 1098, 15 September, Washington, DC: The Heritage Foundation, p.2.

28 NATO (2012), "NATO and Mongolia agree programme of cooperation," 19 March, http:// www.nato.int/cps/en/natolive/news_85430.htm (accessed 7 November 2017). 
that Mongolia would now seek full membership in the SCO. Even both Russia and China are insisting that the observer status of Mongolia in SCO should be changed to the status of a full member (Kamalov2010:241). In terms of regionalisation efforts in Asia, Northeast Asia has been one region where both Russia and Mongolia have enduring interests, particularly since the beginning of the twenty-first century (Soni 2013:297). The two countries' interests in the Northeast Asian region have contributed much to strengthen their bilateral and multilateral relations of which the regional factor has its own significance. Since Northeast Asian nations are getting involved in the regional integration processes with different intensity, developing strategic partnership with Russia has become a natural choice for Mongolia in pursuing its national interests. By supporting Mongolia for its involvement in the Northeast Asian regional integration process, Russia has an opportunity to find its own "niche" as well in the region. ${ }^{29}$

Mongolia's engagement with Russia in the framework of developing strategic partnership is also important because both the countries have distinct geopolitical needs: ${ }^{30}$ For Russia, Mongolia traditionally provides a strategic buffer from China, while Mongolia increases Russia's stake in Sino-Russian relations and offers leverage for Moscow when dealing with Beijing. In recent years, Russia has resumed its military assistance to Mongolia quite actively through training, equipment and exercise. For Mongolia, Russia has been the only source of political, economic, and military support in the face of an assertive China. Nevertheless, other than the benefits Mongolia enjoys across its political, economic and security segments, developing its relations with Russia also has significant strategic value in three important ways as described by Jeff Reeves, which are as follows: ${ }^{31}$

(1) Expanding strategic partnership with Russia ensures Mongolia to continue with its 'balanced relationship' approach with the two neighbours in the face of China's growing influence, especially on Mongolia's trade and economy. For Mongolia, the more developed its relations with Russia become, the more Mongolia can manage these relations to balance China's dominance;

(2) Expanding strategic partnership with Russia increases stability for Mongolia within the Shanghai Cooperation Organisation (SCO) and the

\footnotetext{
29 Sharad K Soni (2013), "Russia-Mongolia Relations: The Northeast Asia Factor", in Tulsi Ram and Ajay Patnaik, eds., Eurasian Politics: Ideas, Institutions and External Relations, New Delhi: KW Publishers, p.306.

30 Jargalsaikhan Mendee (2012), "Why is Russia favoured by Mongolia and North Korea?," http://isnblog.ethz.ch/international-relations/why-is-russia-favored-by-mongolia-and-northkorea-2 (accessed 7 November 2017).

31 Reeves, "Russo-Mongolian Relations".
} 
Conference on Interaction and Confidence Building Measures in Asia (CICA). Russia's position in the two organisations provides a balance to China so as to give legitimacy to the claims of equality among member states of SCO and CICA; and

(3) Expanding strategic partnership with Russia also ensures Mongolia's importance in China's "One Belt, One Road" project under which the three sides agreed to create a economic corridor. For Mongolia, a trilateral agreement with Russia and China provides a far more balanced approach to regional security, economic exchange, and political affairs.

It needs to be pointed out that last year on June 23, 2016, a trilateral economic partnership agreement in Tashkent was signed during the $11^{\text {th }} \mathrm{SCO}$ meeting by the Presidents of the three countries- Russia, China and Mongolia. ${ }^{32}$ The agreement contains 32 proposed projects, and sketches out the creation of a joint investment center to assess the financial requirements and feasibility of each of the three participating countries. One of the main parts of the agreement involves cooperation on improving roads and other forms of transportation in the region. The agreement also proposes regular consultations with third-party transport agencies, including railway companies. Even China-Mongolia-Russia Economic Corridor is an important trilateral initiative given that "One Belt, One Road" project "fits together with Russia's transcontinental rail plan and Mongolia's Prairie Road or Grassland Road or the steppe road programme." ${ }^{33}$ The corridor aims at promoting cooperation among three countries in railways, roads, energy resources, logistics, transportation and agriculture. It, thus, appears that Russia's efforts toward this end serve Mongolia's strategic interests exceptionally well.

32 Peter Bittner (2016), "China, Russia, Mongolia Sign Long-Awaited Economic Partnership Agreement", The Diplomat, 28 June, http://thediplomat.com/2016/06/china-russia-mongoliasign-long-awaited-economic-partnership-agreement/ (accessed 9 November 2017).

33 Sharad K Soni (2017), "Gauging the Importance of China-Mongolia-Russia Economic Corridor in 'One Belt, One Road"”, 16 January, http://www.thedialogue.co/gauging-theimportance-of-china-mongolia-russia-economic-corridor-in-one-belt-one-road/ (accessed 10 November 2017). 


\section{Conclusion}

Looking at the foregoing discussions on the expanding vistas of MongoliaRussia strategic partnership since 2000 Ulaanbaatar Declaration it appears that Moscow not only needs "a friendly Mongolia but also a Mongolia strategically allied with Russia". ${ }^{44}$ The argument is that "if Mongolia were to be dominated by China or any other nation, it would represent a dramatic shift in the balanceof-power in the entire region of the Asia and Pacific". Such thoughts have helped build up confidence on both sides to develop their strategic partnership in all areas of mutual concerns. Yet, in order to further strengthen their strategic partnership both Russia and Mongolia have to recognize each other's importance in bilateral and multilateral affairs. Keeping in mind the priorities of Russian foreign policy it is in Russia's interests that Mongolia, as its immediate neighbour, remains a politically stable and economically prosperous state so as to establish a good-neighbour zone around the perimeter of the Russian borders. Similarly, despite Chinese economic dominance Russia as a significant strategic partner remains to be a credible necessity in matters of Mongolia's bilateral and multilateral security concerns. ${ }^{35}$

In addition, although China is by far the bigger trade partner of Mongolia, Russia is the more popular of the two. Mongolia is now looking to Russia for further investment in the jointly owned railway network to benefit from continental trade with China. Since Russia has already agreed to write off the vast majority of Mongolia's outstanding debt to Russia, a total of US \$174.2 million, it may open exciting opportunities for Moscow as well. This is so because Mongolia is a major importer of refined petroleum from Russia in addition to importing goods worth billions of dollars. Hence, Mongolia will continue to be seen as an opportunity for Russian state and private firms. Given that the current Mongolian President Khaltmaagin Battulga is a pro-Russian, he may prefer Russia to balance the influence of China. ${ }^{36}$ But in a complex geostrategic set up, Mongolia after the July 2017 presidential elections appears to be in a rebalancing mode toward Russia and China, and that would be the

${ }_{34}$ G. Tumurchuluun (1999), "Mongolia's Foreign Policy Revisited: Relations with Russia and PRC into the 1990s", in Stephen Kotkin and Bruce A. Elleman, eds., Mongolia in the Twentieth Century: Landlocked Cosmopolitan, Armonk, New York: M.E.Sharpe, p.282.

35 Vaishali Krishna (2016), "Mongolia's Relations with Russia: Security Dimension”, in Sharad K Soni, ed., Mongolia Today: Internal Changes and External Linkages, New Delhi: Pentagon Press, p. 172 .

36 Vaishali Krishna (2017), "Mongolia appears to be in a rebalancing mode toward Russia and China", The Dialogue, 13 August, http://www.thedialogue.co/mongolia-appears-rebalancingmode-toward-russia-china-2/ (accessed 10 November 2017). 
best strategy to gain maximum benefits. Even though expanding strategic partnership as of now remains to be a major factor in Mongolia-Russia existing relationship. 